\title{
The Formation of Polyploidy on Cyprinus carpio Linn Punten Race by Heat Shocking Temperature
}

Muhammad Khalifah Mustami*

Department of Biology Education, Islamic State University of Alauddin Makassar, Indonesia

\begin{abstract}
Cyprinus carpio Linn is a kind of fresh water fish which is widely developed because the society likes it. Therefore, an appropriate plantation system is needed in order the available fish abounds. Plantation with sterile fish is one of the alternatives of providing the fish appropriately. The research was aimed to know the result of the forming of polyploidy on Cyprinus carpio Linn Punten race given heat shocking temperature after fertilization. The research design used is Completely Randomized Design with four times repeating for each experimental group. The data was analyzed using one-way ANOVA to know the effect of heat shocking temperature treatment toward the result of the formation of polyploidy. The finding of the research shows highly significant differences among the treatments toward the result of the polyploidy with 0,00 probabilities.
\end{abstract}

Keywords: Polyploidy; Cyprinus carpio Linn; Heat shocking temperature

\section{Introduction}

Cyprinus carpion Linn is a freshwater fish species that have a great potential to be developed and the growth of the production is good to be stimulated in order to meet the community nutrition. This is reasonable because the carp has high nutrient content and preference [1]. Cyprinus carpio Linn Punten race has certain advantages, particularly the rapid growth with good and thick quality meat.

The right program in genetic improvement effort is required in order to form a superior seed. In addition to superior seed, the production of sterile fish $(3 \mathrm{~N})$, which is ready to be consumed with a relatively short period of maintenance, needs to be done. It was proposed by Solar et al., Quilled et al. and Penman [2-4] that the fish that have three sets of chromosomes $(3 \mathrm{~N})$ has a faster growth compared to the normal $(2 \mathrm{~N})$. Therefore, Piferrer and Hulata $[5,6]$ suggested that triploid application on the fishing industry is very promising.

Arai and Rustidja [7,8] assumed that the speed of growth of polyploidy, particularly for triploid fish to be sterile, is possible. When gonad develops, the chromosomes cannot carry out the process of pairing. Then, finally, gonads cannot develop (sterile). According to Tabarini [9], the sterility of polyploidy animals is caused by the inability of homologous chromosomes in shaping the synapse during the meiosis.

Myers and Rustidja [8] manipulated the chromosomes in producing polyploidy fish, especially tripod and tetraploid manually by using physical agents such as heat temperature, cold temperature, and the pressure on zygote. Johnstone and Penman $[4,10]$ suggested that the administration of the agent occurs before jumping to polar body II for triploid production and after jumping to polar body II for the production of tetraploid. According to Refstie et al. [11], it is easy to form the triploid fish theoretically. That is tetraploid fish $(4 \mathrm{~N})$ mated with normal fish $(2 \mathrm{~N})$. Experiments using physical agents mentioned above for producing triploid fish has been done by the previous researchers like Tabarini [9] on Argopecten irradians fish, Johnstone [10] on Atlatin salmon fish, Quilled [3] on Crassosterea gigas fish, and Penman [4] in Oreochromis niloticus and Grass carp fish.

\section{Research Methods}

This research is a pure experiment aimed to determine the effect of heat shocking temperature $40^{\circ} \mathrm{C}$ for 2 minutes given at minute $3,10,17$,
24, and 31 after fertilization to the formation of polyploidy on Cyprinus carpio Linn Punten race. The research design used is Completely Randomized Design with four replications for each experimental group. Animal testing becoming the subject of this research is the seed carp Punten race obtained from artificial fertilization. The evaluation of polyploidy formation was done by checking the preparations. Then, the data was recorded using the formula of Carman [12] to determine the percentage of polyploidy formation. The data were analyzed by One Way ANOVA inferential statistics to determine the effect of the treatment.

\section{Findings}

The formation of polyploidy on Cyprinus carpio Linn Punten race obtained during the research can be seen in Table 1.

Based on Table 1 above, it can be said that the formation of polyploidy T1 treatment provides the highest triploid and T5 treatment provides the highest tetraploid formation.

Based on the calculation of the maximum number of nucleoli on Cyprinus carpio Linn Punten race through preparations with dye $\mathrm{AgNO}_{3}$, it is known that diploid (2N) maximum has 2 nucleol, triploid $(3 \mathrm{~N})$ maximum has 3 nucleoli, and tetraploid $(4 \mathrm{~N})$ maximum has 4 nucleoli as in Figure 1.

Based on the calculation of the numbers of chromosome on Cyprinus carpio Linn Punten race through preparations with gymza dye, the diploid numbers of chromosome $(2 \mathrm{~N})$ is known as many as 97 . This means that the numbers of chromosome triploid $(3 \mathrm{~N})$ are 148 and the tetraploid (4N) are 195 as shown in Figure 2.

${ }^{*}$ Corresponding author: Muhammad Khalifah Mustami, Department of Biology Education, Islamic State University of Alauddin Makassar, Indonesia, Tel: 0411 841879; E-mail: khalifahmustami@yahoo.com

Received August 26, 2017; Accepted September 18, 2017; Published September 20, 2017

Citation: Mustam MK (2017) The Formation of Polyploidy on Cyprinus carpio Linn Punten Race by Heat Shocking Temperature. J Aquac Res Development 8: 503 doi: 10.4172/2155-9546.1000503

Copyright: (c) 2017 Mustami MK. This is an open-access article distributed under the terms of the Creative Commons Attribution License, which permits unrestricted use, distribution, and reproduction in any medium, provided the original author and source are credited. 
Citation: Mustam MK (2017) The Formation of Polyploidy on Cyprinus carpio Linn Punten Race by Heat Shocking Temperature. J Aquac Res Development 8: 503. doi: 10.4172/2155-9546.1000503

Page 2 of 4

\begin{tabular}{|c|c|c|c|c|c|c|}
\hline \multirow{2}{*}{ Treatment } & \multirow{2}{*}{ Total Sample } & \multicolumn{3}{|c|}{ Level of Ploidy } & \multicolumn{2}{|c|}{$\%$ The Formation of Polyploidy } \\
\hline & & $\Sigma 2 \mathrm{~N}$ & $\Sigma 2 \mathrm{~N}$ & $\Sigma 2 \mathrm{~N}$ & $3 \mathbf{N}$ & $4 \mathrm{~N}$ \\
\hline T0 & 10 & 10 & 0 & 0 & 0 & 0 \\
\hline $\mathrm{T} 1$ & 10 & 3 & 7 & 0 & 70 & 0 \\
\hline T2 & 10 & 6 & 4 & 0 & 40 & 0 \\
\hline T3 & 10 & 8 & 2 & 0 & 20 & 0 \\
\hline $\mathrm{T} 4$ & 10 & 5 & 1 & 4 & 10 & 40 \\
\hline T5 & 10 & 2 & 0 & 8 & 0 & 80 \\
\hline
\end{tabular}

T0 $=$ Control

$\mathrm{T} 1$ = Shocking in the 3rd minute after fertilization

T2 $=$ Shocking in the 10th minute after fertilization

T3 $=$ Shocking in the 17 th minute after fertilization

T4 = Shocking in the 24th minute after fertilization

$\mathrm{T} 5=$ Shocking in the 31st minute after fertilization

Table 1: The formation of polyploidy on Cyprinus carpio Linn punten race by heat shocking temperature $40^{\circ} \mathrm{C}$ for 2 minutes given at minute $3,10,17,24$, and 31 after fertilization.

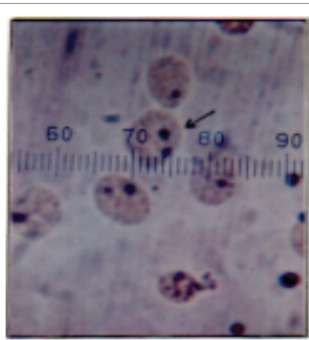

$\mathbf{A}$

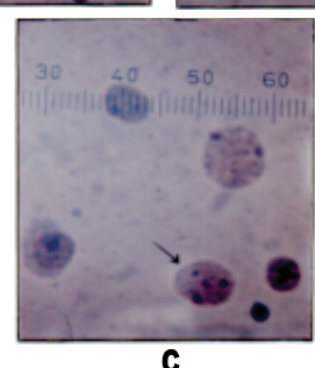

Figure 1: The maximum number of nucleolus on Cyprinus carpio Linn Diploid $2 \mathrm{~N}(\mathrm{~A})$, Triploid; 3N (B), and Tetraploid; 4N (C) in 895 times magnification.

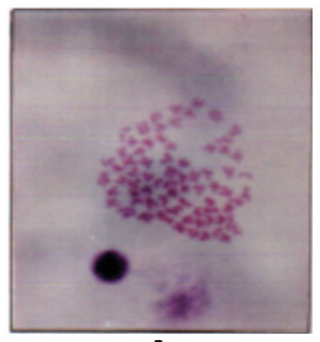

A

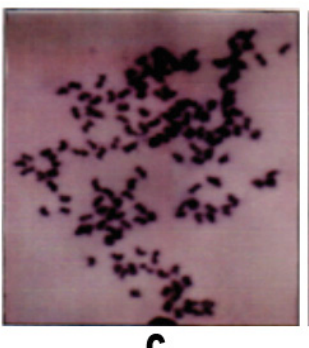

C

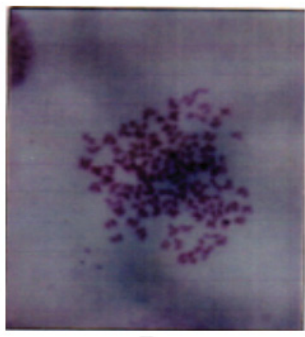

B

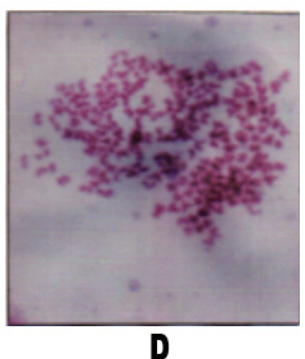

Figure 2: The total number of chromosomes on Cyprinus carpio Linn is less than diploid mode; $2 \mathrm{~N}(\mathrm{~A})$, Diploid; $2 \mathrm{~N}(\mathrm{~B})$, Triploid; 3N (C) and Tetraploid; $4 \mathrm{~N}$ (D) at magnification 2.237 times.

\section{Discussion}

\section{The findings of polyploidy}

The determination of ploidy level in this study used the indirect method by calculating the number of nucleolus and the direct method by calculating the number of chromosomes. Based on the calculation of the number of nucleoli in preparations with $\mathrm{AgNO}_{3}$ dye, the maximum numbers of nucleoli on Cyprinus carpio Linn Punten race diploid $(2 \mathrm{~N})$ have a maximum of 2 nucleoli, triploid ( $3 \mathrm{~N})$ maximum of 3 nucleoli, and tetraploid $(4 \mathrm{~N})$ up to 4 nucleoli. These findings are in line with the findings from [12] in the Common carp.

Carman et al. [12] explained that the diversity of the maximum number of nucleoli in each cell is caused by the merger and or the separation of the nucleolus when the physiological processes during the cell cycle formed the nucleoli less or a lot. Phillips [13] explained that the possibility of cells that have a few number of nucleoli is due to the incorporation of NORs, while the possibility of cells that have a lot of number of nucleoli is caused by the separation of nucleolar during the chromosome formation at the different locations within the cell.

The numbers of chromosome in the fish sample in this research are 97 diploids, 148 triploid, and 195 tetraploid chromosomes. This amount is different from the specified by Gyldenholm et al. [14] on Cyprinus carpio Linn with unclear race. This amount is also different from the results of the research done by Carman [12] in the common carp Cyprinus carpio, which is still similar to the fish sample, only the race makes it different. [14] found that the numbers of diploid chromosome in the Common Carp Cyprinus carpio are as many as 100 chromosomes and triploid as many as 150 chromosomes.

Differences in chromosome number obtained by the numbers of chromosome in a similar research are caused by the different race of the fish sample in the study as a result of chromosome aberration events. According to Suzuki et al., Roberties et al. Russell et al. [1517], with aberration events, it is possible to change in the number and structure of chromosomes. Furthermore, Russell et al. [17] explained that the event may occur spontaneously or for a cause such as radiation, ionization, chemical, and physical stress such as temperature.

\section{The findings of triploidy}

In this study, the number of different data was obtained about triploidisation with heat shocking $40^{\circ} \mathrm{C}$ temperature. The formation of triploid and the results of triploid obtained show 3 minutes heat shocking temperature after fertilization, the formation of triploid is $70 \%$ with the result of triploid $20.3 \%, 10$ minutes heat shocking 
temperature after fertilization, the formation of triploid is $40 \%$ with the result of triploid $13.0 \%, 17$ minutes heat shocking temperature after fertilization, the formation of triploid is $20 \%$ with the result of triploid $8.5 \%, 24$ minutes heat shocking temperature after fertilization, the formation of triploid is $10 \%$ with the result of triploid $4.9 \%, 31$ minutes after fertilization yield $0 \%$ both in the formation and the results of the triploid. The difference of the triploid after being analyzed statistically with One Way ANOVA show highly significant differences among the treatments.

The data above shows the results of 3 minutes heat shocking temperature after fertilization $(20.3 \%)$ is better than the results of 10,17 , and 24 minutes heat shocking temperature after fertilization respectively $13.0 \%, 8.5 \%$, and $4.9 \%$. In other words, there is a tendency that the earlier the provision of heat shocking temperature done to form the triploid, the result will be better. This is confirmed by the further tests result of BNT which show that 3 minutes heat shocking temperature after fertilization gives the highest result of triploid and 24 minutes heat shocking temperature after fertilization gives the lowest outcome.

Based on the triploid data, it can be concluded that the possibility of a polar body II on Cyprinus carpio Linn Punten race occurs between the third and tenth minute after fertilization. Therefore, to form a triploid is after the third minute and before the tenth minute after fertilization for $40^{\circ} \mathrm{C}$ temperature with a shocking two minutes long.

The finding of triploid in this study is different from the findings of similar studies. For instance, similar study conducted by Solar [2] at Rainbow trout with heat shocking temperature $28^{\circ} \mathrm{C}$ in 1 minute and 40 minutes after fertilization for 10 minutes showed the results of triploid respectively $83 \%$ and $100 \%$. Research from Cassani [18] on Ctenopharyngodon idella val with heat shocking temperature $40^{\circ} \mathrm{C}$ in 4.75 minutes after fertilization for 1 minute showed the results of triploid $8 \%$, while the heat shocking temperature $50-70^{\circ} \mathrm{C}$ in $20-45$ minutes after fertilization for 25-30 minutes showed the results of triploid between $50-100 \%$. The research from Johnstone [10] on Atlantic salmon with a heat shocking temperature $30^{\circ} \mathrm{C}$ in 20 minutes after fertilization for 4 and 10 minutes showed the results of triploid respectively $21.6 \%$ and $67 \%$. Research done by Quilled [3] on Crassostrea gigas with heat shocking temperature $35^{\circ} \mathrm{C}$ and $38^{\circ} \mathrm{C}$ in $10-15$ minutes and $35-40$ minutes after fertilization for 10 minutes showed the results of triploid respectively $25 \%$ and $45 \%$. Then, for the shocking 20 minutes long, it showed the results of triploid 60\%. Research conducted by Arai [7] on Salmo trutta with a heat shocking temperature of $29^{\circ} \mathrm{C}$ in 5 minutes and 15 minutes after fertilization for 10 minutes showed the results of triploid respectively $88.2 \%$ and $90.9 \%$, and heat shocking temperature in 5 and 15 minutes for 10 minutes after fertilization showed the results of triploid respectively $50 \%$ and $62.5 \%$.

The existence of the difference in the results of triploid in similar study as mentioned above, it seems to be determined by the factors of required fish, the initiation of shocking, treatment temperature, and the duration of a heat shocking temperature. This is consistent with the explanation from Penman [4] that there are at least three factors that need to be considered dealing with the shocking temperature treatment to form the polyploid, namely the initiation of shocking, shocking duration, and the intensity of shocking.

The success of forming triploid, especially to the fish, is an expected thing in the world's fisheries because triploid fish provides many advantages, especially in the procurement of fish quickly harvested. It is based on the explanation of Solar and Cassani $[2,18]$ that triploid fish is sterile which its development grows faster, more efficient feed conversion, and the mortality rate are lower than diploid fish for some species. In addition to the advantages above, triploid fish can also be used to produce diploid gynogenesis that may have high homozygous Vejaratpimol [19]. Triploidisation fish is also beneficial to the class of salmonid fish which, if reached mature gonads, its mortality increase and its growth rate decrease which in turn decrease the supply of marketable fish meat [11].

The sterility in triploid fish that provides many advantages occurs because triploid fish has three sets of chromosomes as a result of an imbalance genetic during meiosis [20]. That condition causes the chromosome could not pair resulting to the difficulty in undergoing the meiosis because the chromosomes cannot be divided into two haploid sets which are the same. Thus, the growth of the gonad is abnormal.

\section{The Findings of Tetraploid}

In this study, a number of different data about tetraploidisation was obtained by heat shocking temperature of $40^{\circ} \mathrm{C}$ for 2 minutes. The formation of tetraploid and the result of tetraploid obtained show in 24 minutes heat shocking temperature after fertilization, the formation of its tetraploid is $40 \%$ with the result of tetraploid $19.8 \%$, and in 31 minutes heat shocking temperature after fertilization, the formation of its tetraploid is $80 \%$ with the result of tetraploid $38.4 \%$. Heat shocking temperatures are at 3,10 , and 17 minutes after yield $0 \%$, either in the formation or in the result of tetraploid. The difference of the result of tetraploid after statistically analyzed with One Way ANOVA show highly significant differences among the treatments.

The data above show the result of shocking temperature of tetraploid in 31 minutes after fertilization $(38.4 \%)$ is better than the shocking temperature of tetraploid in 24 minutes after fertilization $(19.8 \%)$. In other words, there is a tendency that the longer the provision of shocking temperature after fertilization, the result of its tetraploid is better chances. This is confirmed by the further tests result of BNT which show that 31 minutes heat shocking temperature after fertilization gives the highest result of triploid and 24 minutes heat shocking temperature after fertilization gives the lowest outcome. The different result of this tetraploid differs significantly.

Based on the data of tetraploid, it can also be said that 1) the possibility of forming tetraploid maximally for $40^{\circ} \mathrm{C}$ is for 2 minutes, in contrast to the minutes between 24 and 31 or even above 31 minutes after fertilization and 2) the possibility of mitoisis I on Cyprinus carpio Linn Punten race for going well is after 24 minutes of post-fertilization. It means that after completion, it jumps to polar body II.

The result of tetraploid in this study is different from the results of some similar studies. For instance, a study done by Tave [20] on Channel catfish with shocking temperature $43^{\circ} \mathrm{C}$ combination of 80,85 , and 90 minutes after fertilization during 1-minute show the results of tetraploid respectively $62 \%$ and $40 \%$. The research conducted by Myers [21] on Oreochromis spp. using a combination of pressure of $5.2 \times 10^{4}$ $\mathrm{kPa}(7500 \mathrm{psi})$ with temperature $7.5^{\circ} \mathrm{C}$ show the results of tetraploid between $5-20 \%$.

The existence of the difference in the results of triploid in some similar study is determined by the factors of required fish, the initiation of shocking, treatment temperature, and the duration of heat shocking temperature. This is consistent with the explanation from Penman [4] that there are at least three factors that need to be considered dealing with the shocking temperature treatment to form the polyploid, namely the initiation of shocking, shocking duration, and the intensity 
Citation: Mustam MK (2017) The Formation of Polyploidy on Cyprinus carpio Linn Punten Race by Heat Shocking Temperature. J Aquac Res Development 8: 503. doi: 10.4172/2155-9546.1000503

of shocking. For more specific, Refstie [11] explained that the use of different techniques in manipulating chromosomes will give different results.

The success in forming tetraploid on Cyprinus carpio Linn Punten race with a shocking temperature lies in the results of fertile in order the results of tetraploid can be used in producing triploid carp. Theoretically, Refstie, Tave and Myers [11,20,21] explained that when the tetraploid fish is mated with normal (diploid; $2 \mathrm{~N}$ ), it will produce triploid derivatives. It has been proved by Chourrout [22] in Myers [21] on Salmo gairdneri.

Dealing with the generative between tetraploid fish and diploid fish, the logic of mating tetraploid fish needs to be considered. According to Tave [20], the micro Pyle eggs of diploid fish are not large enough to accept the sperm from the tetraploid fish. Based on this explanation, it can be said that the generative between the tetraploid and diploid is successful if the fish used is female and the diploid is male. If the finding is successful on the Punten race carp, it is expected to no longer need to produce triploid fish manually but just with the natural generative. Thus, the supply of triploid seed is possible more quickly, which in turn the supply of Cyprinus carpio Linn remains available.

\section{Conclusion}

Based on the findings of the research and the discussion that has been done, it can be concluded as the followings:

1. The provision of heat shocking in minute $3,10,17,24$ and 31 with the duration of 2 minutes after fertilization is able to form polyploid on Cyprinus carpio Linn Punten race, particularly for triploid and tetraploid with significantly different results.

2. Total nucleolus of diploid on Cyprinus carpio Linn Punten race has a maximum of 2 nucleoli, triploid has a maximum of 3 nucleoli, and tetraploid has a maximum of 4 nucleoli.

3. The numbers of chromosome of diploid on Cyprinus carpio Linn Punten race is 97 chromosomes and tetraploid as many as 195 chromosomes.

\section{References}

1. Arsyad H, Dan Hadirini RE (1991) Penuntun Praktis Budidaya Perikanan. Mahkota, Jakarta, Indonesia.

2. Solar II, Donaldson EM, Dan Hunter GA (1984) Induction of triploidy in rainbow trout (Salmo Gairdneri Richardson) by heat shock, and investigation of early growth. Aquaculture 42: 57-69.
3. Quilled E, Dan Panelay PJ (1986) Triploidy induction by thermal shocks in the Japanese Oyster, Crassostre Gigas. Aquaculture 57: 271-279.

4. Penman DJ (1993) Genetic manipulation. Institute of Aquaculture, Scotland

5. Piffere F, Beaunont A, Falquiere JC, Flasjshans M, Haffray P, et al. (2009) Poliploid fish and shellfish: Production, biology and application to aquaculture for performance improvement and genetic containment. Aquculture 293: 125-156.

6. Hulata G (2001) Genetic manipulations in aquaculture: a review of stock improvement by classical and modern technologies. Genetica 111: 155-173.

7. Arai K, Dan Wilkins NP (1987) Triploidization of brown trout (Salmon trutta) by Heat Shock. Aquaculture 64: 97-103.

8. Rustidja (1991) Aplikasi Manipulasi Kromosom pada Program Pembenihan Ikan. Makalah pada Kongres IImu Pengetahuan Nasional V di Jakarta: 3-7.

9. Tabarini CL (1984) Induced triploidy in the bay scallop, Argopecten irradians, and Its Effect on Growth and Gametogenesis. Aquaculture 42: 151-160.

10. Johnstone R (1985) Induction of triploidy in Atlantic salmon by heat shock. Aquaculture 49: 133-139.

11. Refstie T, Vassvik V, Dan Gjedrem T (1977) Induction of polyploidy in salmonids by cytocalasin B. Aquaculture 10: 65-74.

12. Carman O, Oshiro T, Dan Takashima F (1991) Estimation of effective condition for induction of triploidy in goldfish. Caurassius auratus Linnaeus. Tokyo University of Fisheries 78: 127-135

13. Phillips RB, Zajicek KD, Ihssen PE, Dan Johnson O (1986) Application of silver staining to the identification of triploid fish cells. Aquculture 54: 313-319.

14. Gyldenholm AO, Dan Scheel JJ (1971) Chromosome numbers of fishes I. Fish Biologi 3: 479-486

15. Suzuki DT, Dan Griffith AJF (1976) Genetic analysis. W.H. Freeman and Company, San Fransisco, USA.

16. Roberties EDP (1980) Cell and molecular biology. Sounders College, Philadelphia, USA.

17. Russell PJ (1992) Genetics.Harper Collins Publisher, USA.

18. Cassani JR, Dan Caton WE (1986) Growth comparisons of diploid and triploid grass carp under varying PM1 conditions. The Progressive Fish Culturist 48:184-187.

19. Vejaratpimol R, Dan Pewnim T (1990) Induction of triploidy in Clarias macrocephalus by cold shock. Asian Fisheries, Thailand: Department of Chemistry.

20. Tave D (1993) Genetics for fish hatchery managers. An AVI Book, New York, USA.

21. Myers JM (1986) Tetraploid induction in Oreochromis spp. Aquaculture 57: 281-287.

22. Chourrout D, Dan Happe A (1986) Improved of direct choromosome preparation in rainbow trout, Salmo gairdneri. Aquaculture 52: 255-261. 